\title{
RELATIONSHIP BETWEEN CRITICAL THINKING SKILLS AND STUDENTS' DECISION-MAKING SKILLS ON VIRUS MATERIALS IN MAN 1 TASIKMALAYA
}

\author{
Lutfia Fajriah*, Endang Surahman, Romy Faisal Mustofa \\ PendidikanBiologi, Fakultas Keguruan dan Ilmu Pendidikan, Universitas Siliwangi \\ Jl. Siliwangi No.24 Kota Tasikmalaya Kode Pos 46115 \\ *lutfiafajr2497@gmail.com
}

Doi: $10.31943 /$ mangiferaedu.v6il.115

Received: November 28, $2020 \quad$ Accepted: May 2, $2021 \quad$ Published: July 31, 2021 Citation: Fajriah, L., Surahman, E, \& Mustofa, F.R, (2021). Relationship Between Critical Thinking Skills Aand Students' Decision-Making Skills On Virus Materials in MAN 1 Tasikmalaya. Jurnal Mangifera Edu, 6(1), 68-81

\begin{abstract}
This research aims to find out the relationship between critical thinking skills and the decision-making skills of students on viral material in MAN 1 Tasikmalaya Regency. The research method used is correlational. The population in this study was all students of class $X$ MIPA consisting of 8 classes. The sample technique uses purposive sampling with samples class X MIPA 3, X MIPA 4, and X MIPA 5 with the number of 107 students.Data collection techniques using instruments in the form of tests. The research instrument used in this study consists of 2 instruments, namely critical thinking skills instruments in the form of a question in the form of a description, as many as 10 questions with 5 indicators. For the instrument of decision-making skills in the form of a question in the form of a description, as many as 12 questions with 5 indicators. The data analysis technique used is a bivariate correlation test. Based on the results of research shows that critical thinking skills have a weak relationship with decision-making skills. This is evidenced by a correlation coefficient value of 0.208 with a determination coefficient value of $4.3 \%$.
\end{abstract}

Keywords: Critical thinking skills, Decision making skills, Virus material.

\section{ABSTRAK}

Penelitian ini bertujuan untuk mengetahui hubungan antara keterampilan berpikir kritis dengan keterampilan pengambilan keputusan peserta didik pada materi virus di MAN 1 Kabupaten Tasikmalaya. Metode penelitian yang digunakan adalah korelasional. Populasi dalam penelitian ini adalah seluruh peserta didik kelas X MIPA yang terdiri dari 8 kelas. Teknik sampel menggunakan purposive sampling dengan sampel kelas X MIPA 3, $X$ MIPA 4, dan X MIPA 5 dengan jumlah 107 peserta didik. Teknik pengumpulan data menggunakan instrumen berupa tes. Instrumen penelitian yang digunakan dalam penelitian ini terdiri dari 2 instrumen yaitu instrumen keterampilan berpikir kritis dalam bentuk soal berupa uraian, sebanyak 10 butir pertanyaan dengan 5 indikator. Untuk instrumen keterampilan pengambilan keputusan dalam bentuk soal berupa uraian, sebanyak 12 butir pertanyaan dengan 5 indikator. Teknik analisis data yang digunakan adalah uji korelasi bivariat. Berdasarkan hasil penelitian menunjukkan bahwa keterampilan berpikir kritis memiliki hubungan yang lemah dengan keterampilan pengambilan keputusan. Hal ini dibuktikan dengan nilai koefisien korelasi sebesar 0, 208 dengan nilai koefisien determinasi sebesar $4,3 \%$. 
Kata Kunci: Keterampilan berpikir kritis, Keterampilan pengambilan keputusan, Materi virus.

\section{PENDAHULUAN}

Keterampilan-keterampilan penting di abad ke-21 masih relevan dengan empat pilar pendidikan yang mencakup learning to know, learning to do, learning to be dan learning to live together. Empat prinsip tersebut masing-masing mengandung keterampilan khusus yang perlu diberdayakan dalam kegiatan belajar, seperti keterampilan berpikir kritis, pemecahan masalah, keterampilan pengambilan keputusan, metakognisi, keterampilan berkomunikasi, berkolaborasi, inovasi dan kreasi, literasi informasi, dan berbagai keterampilan lainnya. Dengan adanya pendidikan diharapkan dapat mempersiapkan peserta didik yang memiliki berbagai keterampilan yang dibutuhkan untuk menghadapi tantangan dalam berkompetisi secara global pada abad ke-21 satu ini.

Perkembangan ilmu pengetahuan dan teknologi pada abad 21 membawa implikasi pada dunia pendidikan yang dituntut untuk beradaptasi dalam kompetensi. Di Indonesia adaptasi tersebut berupa pemberlakuan kurikulum 2013 edisi revisi 2017 dipandang sebagai wahana mengembangkan keterampilan berpikir tingkat tinggi atau Higher Order Thingking Skills (HOTS) bagi peserta didik (Agustini \& Fajriyah, 2017). Keterampilan berpikir yang dibutuhkan dalam era globalisasi ini adalah keterampilan berpikir tingkat tinggi/HOTS yang saat ini telah menjadi salah satu tujuan pembelajaran abad 21 dan arah pengembangan kurikulum 2013 di Indonesia. Baik berpikir kritis maupun pengambilan keputusan termasuk ranah dari HOTS. Selain itu kurikulum 2013 edisi revisi 2017 juga menuntut keterampilan abad 21 dimana berpikir kritis erupakan salah satu komponen terpenting keterampilan abad 21 (Kementrian Pendidikan dan Budaya (Kemendikbud, 2017).

Pada dasarnya semua orang mampu berpikir kritis, namun ada yang terampil dan yang tidak terampil. Kualitas hidup seseorang tergantung dari bagaimana kualitas berpikir kritisnya. Melalui berpikir kritis, kualitas hidup dapat meningkat. Peningkatan tersebut dapat dimulai dengan mengambil keputusan yang lebih berkualitas (Paul \& Elder, 2002). Seseorang dalam kehidupan bermasyarakat dituntut terampil mengambil keputusan, karena keputusan yang didasari pertimbangan ilmiah dibutuhkan untuk memutuskan hal-hal yang berkaitan tidak sekedar untuk kepentingan diri sendiri, tetapi juga memperhatikan kepentingan orang lain, masyarakat, bangsa bahkan negara. Pertimbangan ilmiah untuk mengambil keputusan dapat diperoleh dengan berpikir kritis. Salah satu materi biologi yang mendukung proses berpikir kritis dan pengambilan keputusan ini adalah materi pada kelas 
$\mathrm{X}$ semester ganjil mengenai virus. Pada materi virus peserta didik dituntut untuk melakukan proses berpikir kritis dan mengambil keputusan dalam memecahkan berbagai kasus virus yang terjadi di lingkungan sekitar, berdasarkan hal tersebut virus merupakan materi yang memerlukan pemahaman yang mendalam serta kemampuan berpikir kritis dan keterampilan pengambilan keputusan yang baik dalam menyelesaikan permasalahan-permasalahan yang berkaitan dengan materi tersebut.

Berdasarkan hasil wawancara dengan peserta didik kelas X MIPA pada tanggal 22 Juli 2020, didapatkan informasi bahwa sebagian besar peserta didik masih kesulitan dalam menjawab soal yang membutuhkan analisis meskipun mereka memahami maksud dari soal tersebut, sehingga dari 5 indikator berpikir kritis oleh Ennis (Tawil \& Liliasari, 2013) meliputi memberi penjelasan sederhana, membangun keterampilan dasar, membuat inferensi, membuat penjelasan lebih lanjut, serta mengatur strategi dan teknik. Sebagian besar peserta didik yang diwawancarai masih berada pada tahap memahami apa yang diketahui dan ditanyakan serta guru relatif jarang melakukan tes pengukuran berpikir kritis, padahal berpikir kritis sangatlah penting. Sebenarnya berpikir kritis bertujuan agar peserta didik tidak menerima begitu saja setiap informasi yang diperoleh, namun peserta didik harus berpikir terlebih dahulu serta mempertimbangkan setiap tindakan yang akan dilakukan dalam kegiatan pemecahan masalah. Kemudian peserta didik tidak dapat secara akurat memperkirakan kemungkinan konsekuensi negatif; memiliki waktu yang sulit menafsirkan arti atau kredibilitas informasi ketika membuat keputusan; dipengaruhi oleh emosi mereka dan gagal untuk menggunakan proses pengambilan keputusan. Sehingga, dari beberapa indikator keterampilan pengambilan keputusan menurut Tawil (2013) meliputi membuat pertanyaan apa yang diputuskan, mengumpulkan informasi, menentukan pilihan-pilihan, daftar pro dan kontra, membuat kesimpulan, sebagian besar peserta didik yang diwawancarai belum bisa memenuhi seluruh indikator tersebut. Berdasarkan hasil wawancara didapatkan bahwa guru belum pernah melakukan tes pengukuran keterampilan pengambilan keputusan.

Hubungan antara kedua variabel dalam peneltian ini dapat tercermin dari penelitian yang dilakukan. oleh Latfia (2018) yang menyimpulkan bahwa terdapat hubungan keterampilan berpikir kritis siswa SMP dengan pengambilan keputusan mengenai penggunaan kantong plastik dengan hubungan positif dan signifikan dalam tingkat hubungan cukup. Sementara itu hasil penelitian terdahulu menemukan hubungan yang signifikan antara berpikir kritis dengan pengambilan keputusan klinis (Hedairi \& Ebrahimi, 2016; Hill, 2002). Hasil Penelitian dari Hill (2002) juga menemukan hubungan yang positif dengan tingkat hubungan lemah antara keterampilan berpikir kritis dengan pengambilan keputusan 
dari sampel 110 siswa keperawatan pernapasan.Masalah tersebut menuntut peserta didik untuk memiliki keterampilan berpikir kritis dan pengambilan keputusan, salah satunya dalam menghadapi permasalahan akibat virus. Pendidik dapat mengemas kegiatan pembelajaran yang bertujuan mendorong keterampilan berpikir kritis dengan keterampilan pengambilan keputusan dimana hal itu menjadi kesempatan bagi peserta didik untuk belajar dan mempraktikan kedua keterampilan tersebut. Melihat masih terdapat peserta didik yang belum menyadari bahaya virus sehingga perlu usaha untuk meningkatkan kesadaran peserta didik tentang bahaya virus yang sangat penting diintegrasikan dalam pembelajaran, khususnya pada materi virus.

Masalah tentang virus perlu penanganan yang tepat melalui pengambilan keputusan yang bijak. Sebab pada saat menghadapi sesuatu masalah, manusia perlu mengambil keputusan. Pengambilan keputusan diduga berkaitan dengan proses berpikir untuk memahami inti masalah yang dihadapi dan memikirkan kemungkinan solusi alternatif yang tepat dengan mempertimbangkan dampak dan tiap solusi alternatif tersebut hingga menghasilkan suatu keputusan yang baik. Beranjak dari penelitian-penelitian sebelumnya, juga didasari oleh urgensi keterampilan berpikir kritis dan keterampilan pengambilan keputusan sebagai bagian keterampilan berpikir tingkat tinggi dan maraknya isu tentang bahaya virus yang gencar meminta kesadaran dan kepedulian terhadap diri sendiri dan juga sesama sehingga peneliti semakin tertarik melakukan penelitian, maka dilakukan penelitian dengan judul "Hubungan antara Keterampilan Berpikir Kritis dengan Keterampilan Pengambilan Keputusan pada Materi Virus di MAN 1 Kabupaten Tasikmalaya”. Penelitian ini bertujuan untuk mengetahui hubungan keterampilan berpikir kritis dengan keterampilan pengambilan keputusan peserta didik pada materi virus ditinjau dari korelasi antar skor keterampilan berpikir kritis dan keterampilan pengambilan keputusan peserta didik.

\section{METODOLOGI PENELITIAN}

Penelitian ini menggunakan metode penelitian kuantitatif non eksperimen dengan jenis penelitiannya adalah penelitian korelasional. Menurut Fraenkel \& Wallen (2008) menyatakan bahwa 'Penelitian korelasional adalah suatu penelitian untuk mengetahui hubungan dan tingkat hubungan antara dua variabel atau lebih tanpa ada upaya untuk mempengaruhi variabel tersebut sehingga tidak terdapat manipulasi variabel". Penelitian ini dilakukan pada bulan Oktober semester ganjil tahun ajaran 2020/2021. Sampel pada penelitian ini menggunakan teknik purposive sampling dengan populasi penelitian adalah seluruh kelas X MIPA dengan mengambil responden sebanyak 107 peserta didik. 
Teknik pengumpulan data menggunakan teknik tes berupa soal uraian. Berdasarkan uji validitas dan reliabilitas dengan menggunakan rumus Alpha Cronbach untuk keterampilan berpikir kritis didapatkan 10 butir pernyataan yang valid dan dapat digunakan dengan reliabilitas 0.61 dan untuk keterampilan pengambilan keputusan didapatkan 12 butir pertanyaan yang valid dan dapat digunakan dengan reabilitas 0,75. Data dianalisis dengan menggunakan prasyarat analisis dan uji hipotesis. Uji normalitas dianalisis dengan Kolmogorov-Smirnov dan uji linearitas dianalisis dengan menggunakan test for linearity dengan taraf siginifikansi 5\%.Uji hipotesis dianalisis dengan menggunakan uji korelasi Bivariate pearson dan untuk persamaan regresi dianalisis dengan menggunakan uji $\mathrm{T}$ (Independen T-test). Keseluruhan analisis data dilakukan dengan menggunakan SPSS for windows versi 23 .

\section{HASIL DAN PEMBAHASAN}

Hasil penelitian mengenai hubungan keterampilan berpikir kritis dengan keterampilan pengambilan keputusan disajikan pada tabel berikut ini:

Tabel 1. Statistik keterampilan berpikir kritis dengan keterampilan pengambilan keputusan peserta didik

\begin{tabular}{clcc}
\hline No & \multicolumn{1}{c}{ Statistik } & $\begin{array}{c}\text { Skor peserta didik } \\
\text { keterampilan berpikir } \\
\text { kritis peserta didik }\end{array}$ & $\begin{array}{c}\text { Skor keterampilan } \\
\text { pengambilan } \\
\text { keputusan peserta } \\
\text { didik }\end{array}$ \\
\hline $\mathbf{1}$ & Skor Minimum & 8 & 19 \\
$\mathbf{2}$ & Skor Maksimum & 17 & 39 \\
$\mathbf{3}$ & Rata-rata & 11,76 & 30,63 \\
$\mathbf{4}$ & Standar deviasi & 2,322 & 4.448 \\
$\mathbf{5}$ & Varians & 5,393 & 19.783 \\
& $\quad$ Sumber : Hasil analisis menggunakan software SPSS for windows versi 23
\end{tabular}

Tabel 1 menyajikan data statistik skor hasil tes keterampilan berpikir kritis peserta didik mendapatkan skor minimum 8 , skor maksimum 17 , rata-rata 11.76 , standar deviasi 2.322 dan varians 5.393. Sedangkan skor hasil tes keterampilan pengambilan keputusan peserta didik mendapatkan skor minimum 19, skor maksimum 39, rata-rata 30.63, standar deviasi 4.448 dan varians 19.783 .

Uji prasyarat yang dilakukan untuk data penelitian ini adalah uji normalitas, uji linearitas dan uji hipotesis yang dapat dilihat pada tabel 2 berikut:

Uji prasyarat yang dilakukan untuk data penelitian ini adalah uji normalitas, uji linearitas dan uji hipotesis yang dapat dilihat pada Tabel 2. 
Jurnal Mangifera Edu, Volume 6, Issue 1, July 2021, 68-81

Tabel 2. Hasil uji normalitas dengan kolmogorov-smirnov test

\begin{tabular}{ccccc}
\hline Data & $\mathbf{N}$ & Asymp.Sig (2-tailed) & $\begin{array}{c}\text { Signifikasi } \\
(\boldsymbol{\alpha})\end{array}$ & $\begin{array}{c}\text { Kesimpulan } \\
\text { Analisis }\end{array}$ \\
\hline $\begin{array}{c}\text { Skor kete rampilan } \\
\text { berpikir kritis } \\
\begin{array}{c}\text { Skor kete rampilan } \\
\text { pengambilan } \\
\text { ke putusan }\end{array}\end{array}$ & 107 & 0,051 & 0,05 & Terima Ho \\
\hline & Sumber: Hasil analisis menggunakan SPSS for windows versi 23.
\end{tabular}

Berdasarkan Tabel 2 merupakan data yang berasal dari 107 peserta didik yang telah melakukan tes keterampilan berpikir kritis nilai signifikansinya 0,051 dan keterampilan pengambilan keputusan nilai signifikansinya adalah 0,095 Kedua data tersebut nilai signifikansinya di atas 0,05 yang artinya sampel diambil dari populasi yang berdistribusi normal. Setelah data bersifat normal, maka uji prasyarat dilanjutkan dengan uji linearitas. Pengujian linearitas dengan menggunakan test for linearity dengan taraf signifikasi sebesar $5 \%$ atau 0,05, pengujian data menggunakan bantuan program SPSS for windows versi 23. Adapun hasilnya dapat dilihat pada tabel 3.

Tabel 3. Hasil uji linearitas antara keterampilan berpikir kritis dengan keterampilan pengambilan keputusan peserta didik

\begin{tabular}{ccccc}
\hline Data & $\mathbf{a ~ 0 , 0 5}$ & Signifikansi & Hasil Analis is & $\begin{array}{c}\text { Kesimpulan } \\
\text { Analisis }\end{array}$ \\
\hline $\begin{array}{c}\text { Kete rampilan berpikir } \\
\text { kritis dengan } \\
\text { keterampilan } \\
\text { pengambilan } \\
\text { keputusan }\end{array}$ & 0,05 & 0,915 & Signifikansi $>$ & $\begin{array}{c}\text { Terima Ho } \\
\text { (Kedua } \\
\text { variabel } \\
\text { bersifat Linear) }\end{array}$ \\
\hline & & & 0,05 & \\
\hline
\end{tabular}

Berdasarkan data pada Tabel 3 Nilai signifikansi keterampilan berpikir kritis dengan keterampilan pengambilan keputusan adalah 0,915 lebih besar daripada 0,05 maka dapat ditarik kesimpulan bahwa keterampilan berpikir kritis dengan keterampilan pengambilan keputusan bersifat linear. Selanjutnya pengujian dilanjutkan dengan menggunakan uji korelasi bivariate dengan menggunakan bantuan dari SPSS for windows versi 23 dapat dilihat pada Tabel 4 . 
Jurnal Mangifera Edu, Volume 6, Issue 1, July 2021, 68-81

Tabel 4. Ringkasan hasil kore lasi bivariat

\begin{tabular}{|c|c|c|c|c|c|c|c|c|c|}
\hline \multirow[t]{2}{*}{ Model } & \multirow[t]{2}{*}{$\mathbf{R}$} & \multirow{2}{*}{$\begin{array}{c}\text { R } \\
\text { Square }\end{array}$} & \multirow{2}{*}{$\begin{array}{c}\text { Adjusted } \\
\text { R } \\
\text { Square }\end{array}$} & \multicolumn{2}{|c|}{$\begin{array}{l}\text { Model Summary } \\
\text { Std. }\end{array}$} & \multicolumn{3}{|c|}{ Change Statistics } & \multirow[b]{2}{*}{$\begin{array}{l}\text { Sig. F } \\
\text { Change }\end{array}$} \\
\hline & & & & $\begin{array}{l}\text { the } \\
\text { Estimate }\end{array}$ & $\begin{array}{c}\text { R } \\
\text { Square }\end{array}$ & $\begin{array}{c}\text { F } \\
\text { Change }\end{array}$ & $\begin{array}{l}\text { df } \\
1\end{array}$ & $\begin{array}{l}\text { df } \\
2\end{array}$ & \\
\hline 1 & $\begin{array}{r}.208 \\
\text { a }\end{array}$ & .043 & .034 & 4.372 & $\begin{array}{r}\text { Change } \\
.043\end{array}$ & 4.728 & 1 & $\begin{array}{r}10 \\
5\end{array}$ & .032 \\
\hline a. Prec & rs: (C & $\operatorname{stant}), \mathrm{K}$ & rampilan & rpikir Krit & & & & & \\
\hline
\end{tabular}

Sumber: Hasil pengolahan data menggunakan SPSS versi 23 for windows

Berdasarkan hasil yang tertera dalam Tabel 4 tersebut didapatkan nilai koefisien korelasi (R) sebesar 0,208 dan nilai koefisien determinasi $\left(\mathrm{R}^{2}\right)$ sebesar 0,043 atau 4,3\%. Sehingga dapat disimpulkan bahwa variabel keterampilan berpikir kritis memberikan kontribusi sebesar $4,3 \%$ sedangkan sisanya yakni merupakan variabel lain yang tidak diteliti dalam penelitian ini.

Tabel 5. Rangkuman uji T

\begin{tabular}{|c|c|c|c|c|c|c|}
\hline \multicolumn{7}{|c|}{ UJI T } \\
\hline \multicolumn{2}{|c|}{ Model } & \multicolumn{2}{|c|}{$\begin{array}{l}\text { Unstandar dized } \\
\text { Coefficients }\end{array}$} & \multirow{2}{*}{$\begin{array}{c}\text { Standardize } \\
\text { d } \\
\text { Coefficients } \\
\text { Beta }\end{array}$} & \multirow[t]{2}{*}{$\mathbf{t}$} & \multirow[t]{2}{*}{ Sig. } \\
\hline & & B & $\begin{array}{l}\text { Std. } \\
\text { Error }\end{array}$ & & & \\
\hline 1 & (Constant) & 25.952 & 2.191 & & 11.84 & .000 \\
\hline & $\begin{array}{l}\text { Keterampilan } \\
\text { Berpikir Kritis }\end{array}$ & .398 & . 183 & 208 & $\begin{array}{r}6 \\
2.174\end{array}$ & .032 \\
\hline
\end{tabular}

Sumber: Hasil Pengolahan Data menggunakan SPSS Versi 23 for windows

Berdasarkan Tabel 5 dapat diketahui persamaan regresi $\hat{Y}=a+b x$. Nilai a adalah 25,952 nilai $\mathrm{b}$ adalah 0,398. Sehingga persamaan regresi yang diperoleh $\hat{\mathrm{Y}}=$ 25,952+0,398x. Selain persamaan regresi, Tabel 4.8 juga menunjukan bahwa bentuk hubungan keterampilan berpikir kritis dengan keterampilan pengambilan keputusan bersifat positif.

Penelitian ini bertujuan untuk menguji hubungan antara keterampilan berpikir kritis dengan keterampilan pengambilan keputusan pada materi virus. Penelitian ini dilakukan di kelas X MIPA 3, X MIPA 4 dan X MIPA 5 di MAN 1 Kabupaten Tasikmalaya. 


\section{1) Hubungan antara keterampilan berpikir kritis dengan keterampilan pengambilan keputusan}

Berdasarkan penelitian yang telah dilakukan di kelas X MIPA 3, X MIPA 4 dan X MIPA 5 di MAN 1 Kabupaten Tasikmalaya, diperoleh data keterampilan berpikir kritis dengan keterampilan pengambilan keputusan. Data tersebut diuji dengan uji bivariate dengan bantuan software SPSS versi 23 for windows. Dari hasil uji hipotesis data tersebut menunjukkan bahwa nilai signifikansinya sebesar 0,00 dengan menggunakan taraf siginifikansi $5 \%$ atau 0,05 . Hal ini berarti nilai signifikansi $\leq 0,05$ sehingga kesimpulan hipotesisnya yaitu tolak Ho yang artinya ada hubungan antara keterampilan berpikir kritis dengan keterampilan pengambilan keputusan secara signifikan.

Hubungan antara keterampilan berpikir kritis dengan keterampilan pengambilan keputusan memiliki koefisien korelasi (R) sebesar 0,208 yang berarti tingkat hubungan tersebut bersifat lemah. Sedangkan untuk nilai koefisien determinasi $\left(\mathrm{R}^{2}\right)$ yang diartikan sebagai sumbangan atau kontribusi yang diberikan oleh keterampilan berpikir kritis dengan keterampilan pengambilan keputusan adalah 0,043 atau 4,3\% dan lainnya tidak diteliti pada penelitian ini. Untuk persamaan regresinya yaitu diperoleh $\hat{Y}=25,952+0,398 x$. Secara jelas dapat dilihat di graph scatterplot pada Gambar 4.5.

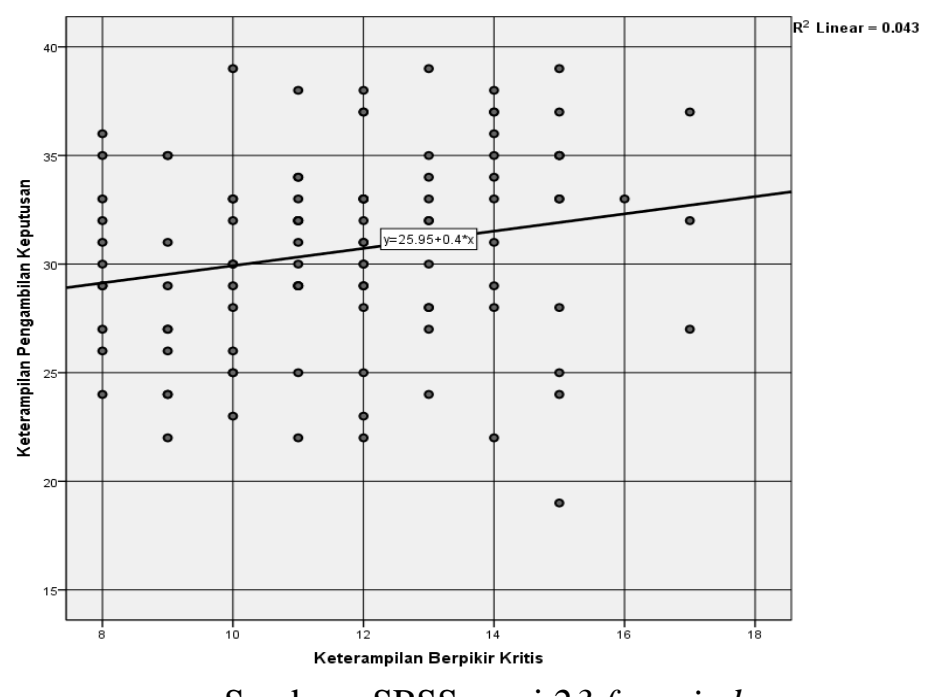

Sumber : SPSS versi 23 for windows

Gambar 4.3 Graph Scatterplot (Bivariate) $=\mathrm{X}$ with $\mathrm{Y}$

Berdasarkan grafik scatterplot tersebut, terlihat pola garis linearitas antara keterampilan berpikir kritis dengan keterampilan pengambilan keputusan pada materi virus. Sementara titik-titik pada plot menunjukkan besarnya penyimpangan (eror) dari hubungan tersebut. Hubungan positif ini dapat bermakna bahwa jika keterampilan berpikir kritis peserta didik mengalami peningkatan maka keterampilan pengambilan keputusan akan 
meningkat pula. Berbagai penelitian yang telah dilakukan sebelumnya menunjukkan adanya hubungan antara keterampilan berpikir kritis dengan ketErampilan pengambilan keputusan pada peserta didik. Sasha elitzar Latfia (2018) yang menyimpulkan bahwa "terdapat hubungan keterampilan berpikir kritis siswa SMP dengan pengambilan keputusan mengenai penggunaan kantong plastik dengan hubungan positif dan signifikan dalam tingkat hubungan cukup". Sementara itu hasil penelitian terdahulu menemukan hubungan yang signifikan antara berpikir kritis dengan pengambilan keputusan klinis (Hedairi \& Ebrahimi, 2016; Hill, 2002). Hasil Penelitian dari Hill (2002) juga menemukan hubungan yang positif dengan tingkat hubungan lemah antara keterampilan berpikir kritis dengan pengambilan keputusan dari sampel 110 siswa keperawatan pernapasan. Hal ini juga membuktikan bahwa keterampilan berpikir kritis memberikan kontribusi terhadap keterampilan pengambilan keputusan. Tingkat hubungan yang lemah ini di pengaruhi beberapa faktor seperti pengetahuan awal peserta didik tentang materi, lingkungan internal dan eksternal peserta didik, serta berpikir kritis tidak menjamin bahwa keputusan akan dibuat dan keputusan dapat dibuat tanpa memproses informasi secara logis.

\section{2) Keterampilan Berpikir Kritis}

Berdasarkan hasil analisis data keterampilan berpikir kritis didapatkan jumlah persentase sebesar 58,79 \%. Persentase tersebut didapatkan dari perhitungan yang terdapat pada lampiran pengolahan data. Dapat diartikan bahwa profil keterampilan berpikir kritis peserta didik di MAN 1 Kabupaten Tasikmalaya termasuk ke dalam kategori cukup. Kategori cukup ini menandakan bahwa tingkat keterampilan berpikir kritis pada peserta didik di MAN 1 Kabupaten Tasikmalaya cukup. Penulis berasumsi bahwa tingkat keterampilan berpikir kritis dengan kategori cukup di MAN 1 Kabupaten Tasikmalaya ini dikarenakan peserta didik kelas X pada dasarnya, semua orang mampu berpikir kritis, namun ada yang terampil dan yang tidak terampil. Kualitas hidup seseorang tergantung bagaimana kualitas berpikir kritisnya. Melalui berpikir kritis, kualitas hidup dapat meningkat. Peningkatan tersebut dapat dimulai dengan mengambil keputusan yang lebih berkualitas (Paul \& Elder, 2002). Seseorang dalam kehidupan bermasyarakat dituntut terampil mengambil keputusan, karena keputusan yang didasari pertimbangan ilmiah dibutuhkan untuk memutuskan hal-hal yang berkaitan tidak sekedar untuk kepentingan diri sendiri, tetapi juga memperhatikan kepentingan orang lain. Pertimbangan ilmiah untuk mengambil keputusan dapat diperoleh dengan berpikir kritis. Keterampilan berpikir kritis turut serta membangun kesadaran masyarakat dalam mengambil keputusan dari suatu masalah. Penelitian keterampilan berpikir kritis menggunakan soal berupa uraian yang terdiri dari 
lima indikator yaitu memberi penjelasan sederhana, membangun keterampilan dasar, membuat inferensi, membuat penjelasan lebih lanjut, serta mengatur strategi dan teknik. Berdasarkan hasil analisis data soal menunjukkan bahwa skor rata-rata keterampilan berpikir perindikator secara lengkap ada pada Gambar 4.4 :

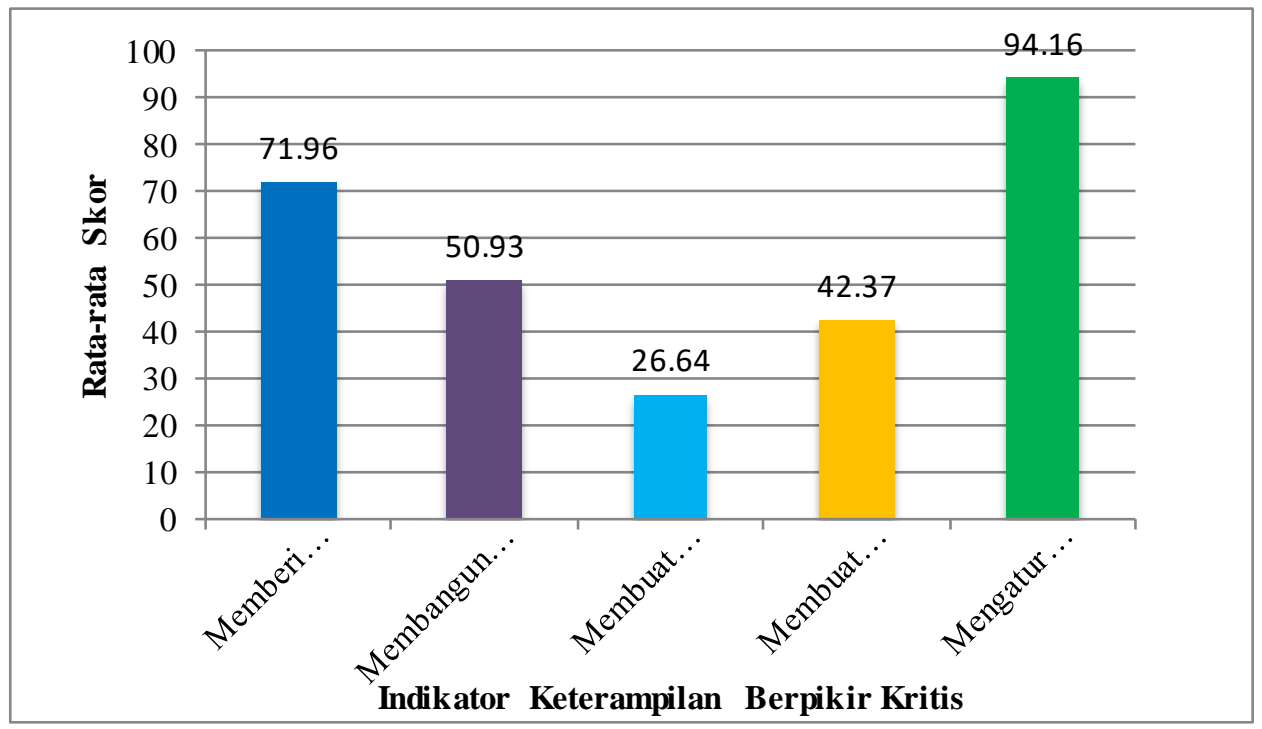

Gambar 1 Diagram batang skor rata-rata perindikator kete rampilan be rpikir kritis

Gambar 1 menyajikan daftar skor rata-rata perindikator pada keterampilan berpikir kritis. Berdasarkan gambar tersebut dapat dilihat bahwa skor rata-rata pada indikator 1 (memberi penjelasan sederhana) sebesar 71.96, untuk indikator 2 (membangun keterampilan dasar) sebesar 50.93, untuk indikator 3 (membuat inferensi) sebesar 26,64, untuk indikator 4 (membuat penjelasan lebih lanjut) sebesar 42.37 dan untuk indikator 5 (mengatur strategi dan teknik) adalah sebesar 94,16. Jadi skor rata-rata indikator terbesar keterampilan berpikir kritis adalah mengatur strategi dan teknik diartikan sebagai taraf berpikir kritis peserta didik untuk memutuskan suatu tindakan dalam tugas yang mampu dilaksanakannya. Sehingga dapat ditarik kesimpulan bahwa peserta didik kelas X MIPA di MAN 1 Kabupaten Tasikmalaya memiliki taraf berpikir kritis yang baik dalam menentukan suatu tindakan tugasnya.

\section{3) Keterampilan Pengambilan Keputusan}

Berdasarkan hasil analisis data keterampilan pengambilan keputusan didapatkan jumlah persentase sebesar 76,57\%. Dimana persentase tersebut didapatkan dari perhitungan yang terdapat pada lampiran pengolahan data. Sehingga dapat diartikan bahwa profil keterampilan pengambilan keputusan peserta didik di MAN 1 Kabupaten Tasikmalaya termasuk ke dalam kategori baik. Penulis berasumsi bahwa tingkat Keterampilan pengambilan keputusan dengan kategori baik di MAN 1 Kabupaten Tasikmalaya 
dikarenakan keterampilan berpikir kritis peserta didik yang cukup. Sejalan dengan pendapat Paul \& Elder (2002) bahwa Dalam menjadi pembuat keputusan yang baik tidak terlepas dari menjadi pemikir yang baik. Penelitian keterampilan pengambilan keputusan menggunakan soal uraian yang terdiri dari lima indikator yaitu membuat pertanyaan apa yang diputuskan, mengumpulkan informasi, menentukan pilihan-pilihan, daftar pro dan kontra, membuat kesimpulan. Berdasarkan hasil analisis data skor keterampilan pengambilan keputusan menunjukkan bahwa skor rata-rata keterampilan pengambilan keputusan perindikator secara lengkap ada pada Gambar 2.

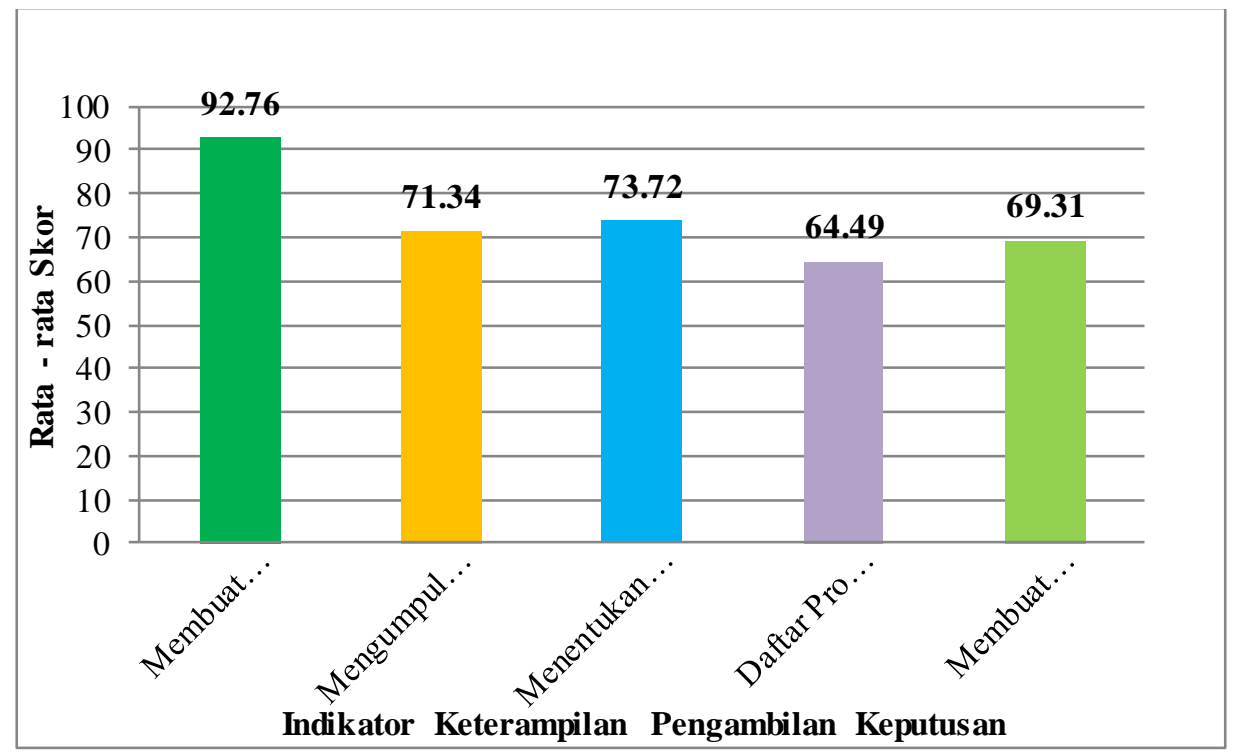

Gambar 2 Diagram batang skor rata-rata perindikator keterampilan pengambilan keputusan

Gambar 2 menyajikan daftar skor rata-rata perindikator pada keterampilan pengambilan keputusan. Berdasarkan gambar tersebut dapat dilihat bahwa skor rata-rata pada indikator 1 (membuat pertanyaan apa yang diputuskan) sebesar 92.76, untuk indikator 2 (menjelaskan informasi) sebesar 71.34, untuk indikator 3 (menentukan pilihan-pilihan) sebesar 73.72, untuk indikator 4 (daftar pro kontra) sebesar 64.49, dan untuk Indikator 5 (membuat kesimpulan) adalah sebesar 69.31. Jadi skor rata-rata indikator terbesar dari keterampilan pengambilan keputusan adalah indikator 1 yaitu membuat pertanyaan apa yang akan diputuskan. Indikator membuat pertanyaan apa yang akan diputuskan diartikan sebagai sebuah kemampuan untuk membantu mengenali masalah dengan bantuan sejumlah pertanyaan $(5 \mathrm{~W}+1 \mathrm{H})$ dan menilai permasalahan ilmiah. Sehingga dapat ditarik kesimpulan bahwa peserta didik kelas X MIPA di MAN 1 Kabupaten Tasikmalaya memiliki kemampuan untuk mengenali dan menilai permasalahan ilmiah dengan baik. 


\section{SIMPULAN}

Berdasarkan hasil penelitian mengenai hubungan keterampilan berpikir kritis dengan keterampilan pengambilan keputusan pada materi virus di MAN 1 Kabupaten Tasikmalaya dapat disimpulkan bahwa terdapat hubungan yang positif dan signifikan dalam tingkat hubungan lemah. Nilai koefisien korelasi (R) yang diperoleh adalah 0,208 dan nilai koefisien determinasi $\left(\mathrm{R}^{2}\right)$ sebesar 0,043 atau 4,3\%. Hal tersebut menunjukan bahwa keterampilan berpikir kritis memberikan kontribusi sebesar 4,3\% terhadap keterampilan pengambilan keputusan peserta didik.

Penulis mengajukan beberapa saran untuk melatihkan keterampilan berpikir kritis dan pengambilan keputusan peserta didik dengan mempertimbangkan alokasi waktu pembelajaran secara efektif, diperlukan penelitian lanjutan mengenai kontribusi lain yang berhubungan dengan keterampilan pengambilan keputusan. Keterampilan berpikir kritis dengan pengambilan keputusan diperkenalkan dan dilatihkan oleh guru melalui kegiatan pembelajaran secara intenstif sehingga peserta didik menyadari pentingnya keterampilan berpikir kritis dan keterampilan pengambilan keputusan di dalam kehidupan dan kemudian termotivasi untuk meningkatkan keterampilan yang dimilikinya.

\section{DAFTAR PUSTAKA}

Agustini, Ferina \& Khusnul Fajriyah. (2017). Problematika Pengembangan HOTS (Higher Order Thingking Skills) Di sekolah Dasar. Jurnal Inovasi Pendidikan.

Arends, Richard. (2009). Learning to Teach (Ninth Edition). New York: Mc-Graw Hill.

Arikunto, S. (2013). Prosedur Penelitian Suatu Pendekatan Praktik. Jakarta: Rineka Cipta.

Arikunto, S. (2016). Dasar-Dasar Evaluasi Pendidikan. Jakarta: Bumi Aksara.

Badarudin. (2017). Pengaruh Keterampilan Pengambilan Keputusan dan Penguasaan Konsep IPA Melalui Model Pembelajaran Advance Organizer di Sekolah Dasar. Jurnal Ilmiah Pendidikan Dasar, 6(1), 8-20.

Creswell, John W.(2012). Educational research : planning, conducting, and evaluating quantitative and qualitative research. New York: University of Nebraska-Lincoln.

Dermawan, Rizki. (2018). Pengambilan Keputusan, Landasan Filosofis, Konsep dan Aplikasi. Bandung: Alfabeta.

Elitzar Latfia, Sasha. (2018). Hubungan keterampilan berpikir kritis siswa smp dengan pengambilan keputusan mengenai penggunaan kantong plastik. Skripsi. Bandung: Universitas Pendidikan Indonesia. 
Fischer, Al. (2009). Berpikir Kritis Sebuah Pengantar. Terjemahan. Jakarta: Erlangga

Fraenkel, Jack.R \& Norma E.Wallen (2009). How to design and evaluate research in education. New York: Mc-Graw Hill.

Heidari, Mohammad \& Ebrahimi. (2016). Examining the relationship between criticalthinking skills an decisions-making ability of emergency medicine students. Indian Society of Critical Care Medicine 20 (10), 581.

Hernawan, Edi. (2018). Pengantar Statistika untuk Penelitian Pendidikan. Tasikmalaya: LPPM Universitas Siliwangi.

Hill T.V. (2002). The relationship between critical thingking and decisions- making in respiratory care students. Respiratory care, 47(5), 571-577.

Kemdikbud. (2016). Hasil TIMSS 2015. [Online]. Diakses dari https://puspendik.kemdikbud.go.id/seminar/upload/Hasil\%20Sem

inar\%20Puspendik\%202016/RahmawatiSeminar\%20Hasil\%20TIMSS\%202015.pdf.

Paul, R. and Elder, L. (2008). The Miniature Guide to Critical Thinking Concepts and Tools. Berkeley: Universitiy of California.

Reece, Jane B. et.al.,.(20). Campbell Biology Tenth Edition. Pearson Education, inc.

Rofiq, Arif ainur. (2015). Pentingnya Keterampilan Pengambilan Keputusan Sosial Bagi Siswa SMP. Jurnal Ilmiah Psikologi, 2(2), 175-184.

Sa'adah, D., Masrukan, \& Kuniasih, A. W. (2017). Pendekatan Metakognisi untuk Meningkatkan Kemampuan Pemecahan Masalah Geometri Kelas VIII. Jurnal Edumath, 3(1), 15-27.

Santrock, J.W.(2011). Educational Psychology (Fifth Edition). Texas: Mc-Graw Hill.

Saputri, A. C., Sajidan, \& Rinanto, Y. (2017). Identifikasi Keterampilan Berpikir Kritis Siswa dalam Pembelajaran Biologi Menggunakan Window Shopping. Seminar Nasional Pendidikan Sains (SNPS), 21, 131-135.

Sastradihardja, Singgih. (2008). Virus dan Bakteri. Bandung: PT Puri Pustaka

Sri harti, Agnes. (2015). Mikrobiologi kesehatan. Surakarta: Penerbit ANDI, Anggota IKAPI.

Suciana, N. (2014). Integrasi Keterampilan Abad 21 dalam Kurikulum 2013 untuk Mewujudkan Indonesia Jaya. Penyelenggara: Sekolah Tinggi Keguruan dan Ilmu Pendidikan SURYA.

Sugiyono, (2012). Metode Penelitian Kuantitatif, Kualitatif dan Kombinasi (Mixed Methods). Bandung: Alfabeta.

Sugiyono. (2015). Metode Penelitian (Kuantitatif, Kualitatif, dan R\&D). Bandung: Alfabeta. 
Jurnal Mangifera Edu, Volume 6, Issue 1, July 2021, 68-81

Tawil, M., \& Liliasari. (2013). Berpikir Kompleks dan Implementasinya dalam Pembelajaran IPA. Makassar: Universitas Negeri Makasar. 